\title{
Article/Artigo
}

\section{Antimicrobial susceptibilities of Listeria monocytogenes human strains isolated from 1970 to 2008 in Brazil}

\author{
Suscetibilidade antimicrobiana de cepas humanas de Listeria monocytogenes isoladas no período \\ de 1970 a 2008 no Brasil
}

\section{Cristhiane Moura Falavina dos Reis ${ }^{1}$, André Victor Barbosa ${ }^{1}$, Leonardo Alves Rusak ${ }^{1}$, Deyse Christina Vallim ${ }^{1}$ and Ernesto Hofer ${ }^{1}$}

\begin{abstract}
Introduction: Listeria monocytogenes is the causative agent of listeriosis, a foodborne illness that affects mainly pregnant women, the elderly and immunocompromised patients. The primary treatment is a combination of ampicillin with an aminoglycoside, in addition to a second-choice drug represented by chloramphenicol, erythromycin, tetracycline and rifampicin. The aim of this study was to analyze the antimicrobial susceptibility profile of strains isolated from human sources in the last four decades. Methods: Sixty-eight strains were selected from the culture collection of the Laboratory of Bacterial Zoonoses/LABZOO/FIOCRUZ isolated in different regions of Brazil from 1970 to 2008 and primarily isolated from cerebrospinal fluid and blood culture. Susceptibility tests to antimicrobials drugs were evaluated using the criteria established by Soussy using the Kirby-Bauer method and E-Test strips were used to determine the minimum inhibitory concentration (MIC). Results: Among the strains tested, serovar L4b (60.3\%) was the most prevalent, followed by serovar $1 / 2 \mathrm{a}(20.6 \%), 1 / 2 \mathrm{~b}(13.2 \%)$ and the more uncommon serovars $1 / 2 c, 3 b$ and $4 a b(5.9 \%)$. All strains were susceptible to ampicillin, cephalothin, erythromycin, gentamicin, teicoplanin and vancomycin. Only one strain (1.5\%) showed resistance to rifampin, and two $(3 \%)$ were resistant to trimethoprim-sulfamethoxazole. MICs with values up to $2 \mu \mathrm{g} / \mathrm{ml}$ reinforce the need for microbiological surveillance. Conclusions: The study demonstrated low prevalence of strains resistant to the antimicrobial drugs indicated in the treatment of human listeriosis. Monitoring antimicrobial resistance profile is still very important to determine adequate treatment, especially in immunocompromised patients.
\end{abstract}

Keywords: Listeria monocytogenes. Antimicrobial susceptibilities. Listeriosis.

\section{RESUMO}

Introdução: Listeria monocytogenes é o agente etiológico da listeriose, doença de origem alimentar que acomete principalmente grávidas, pacientes imunodeprimidos e idosos. $\mathrm{O}$ tratamento primário é a associação de ampicilina a um aminoglicosídeo além de outros, em segunda escolha, representados por cloranfenicol, eritromicina, tetraciclina e rifampicina. O presente estudo teve como objetivo analisar o perfil de susceptibilidade aos antimicrobianos de amostras de origem humana isoladas nas últimas quatro décadas. Métodos: Foram selecionadas 68 cepas provenientes de casos clínicos humanos ocorridos em diferentes regiões do país no período de 1970-2008. A susceptibilidade aos antimicrobianos testados foi determinada através dos critérios estabelecidos por Soussy pelo método de Kirby-Bauer e a concentração mínima inibitória realizada através do E-Test. Resultados: A amostragem constituiu-se de 68 cepas, isoladas principalmente de líquido cefalorraquidiano, e hemocultura no período, pertencentes ao Laboratório de Zoonoses Bacterianas/LABZOO/Fiocruz. O sorovar L4b $(60,3 \%)$ foi o mais prevalente, seguido do sorovar $1 / 2 \mathrm{a}(20,6 \%), 1 / 2 \mathrm{~b}(13,2 \%)$ e aqueles mais raros representados por $1 / 2 c, 3 b$ e $4 \mathrm{ab}(5,9 \%)$. Todas as cepas foram sensíveis à ampicilina, cefalotina, eritromicina, gentamicina, teicoplanina e vancomicina. Apenas uma cepa $(1,5 \%)$ apresentou resistência à rifampicina, enquanto duas (3\%) foram resistentes à associação de sulfametoxazol-trimetoprim. Conclusões: Apesar de o estudo ter demonstrado uma baixa prevalência de amostras resistentes aos antimicrobianos indicados na terapêutica da listeriose humana, o sistema de monitoramento do perfil de resistência antimicrobiana é de extrema importância para a orientação do tratamento adequado, principalmente nas infecções em pacientes imunocomprometidos.

Palavras-chaves: Listeria monocytogenes. Susceptibilidade antimicrobiana. Listeriose.

1. Laboratório de Zoonoses Bacterianas, Instituto Oswaldo Cruz, Fundação Oswaldo Cruz, Rio de Janeiro, RJ.

Address to: Dra. Deyse Christina Vallim. Lab. Zoonoses Bacterianas/IOC/FIOCRUZ. Av. Brasil 4365, Pavilhão Rocha Lima/sala 315, Manguinhos, 21040-900 Rio de Janeiro, RJ, Brasil.

Phone: 5521 2270-6565

e-mail: vallim@ioc.fiocruz.br

Received in 27/10/2010

Accepted in 15/12/2010

\section{INTRODUCTION}

Listeria monocytogenes is a gram positive, facultative anaerobe, intracellular bacterium and the etiologic agent of human and animal listeriosis. The disease affects primarily pregnant women, newborns and patients with degenerative diseases and/or immunocompromised patients, is clinically manifested as meningitis and septicemia, has a high mortality rate, between 20 and $30 \%$ of cases, and causes neurological sequelae in some cases ${ }^{1-3}$.

Members of the genus Listeria are widely distributed in nature and can be detected in the environment (soil, vegetables, silage and water) and in the intestinal tract of humans and animals ${ }^{2}$. The species is a significant food-borne pathogen ${ }^{4}$.

Listeria monocytogenes presents uniform antimicrobial susceptibility, including drugs commonly used for treating human listeriosis, such as ampicillin or in association with an aminoglycoside (e.g. gentamicin), and other second-choice antimicrobials represented by chloramphenicol, erythromycin, tetracycline and rifampicin ${ }^{4-6}$. However, clinical strains resistant to chloramphenicol, erythromycin, streptomycin, tetracycline, vancomycin and trimethoprim have been recently described ${ }^{4}$. The widespread distribution of epidemiologically serotypes of L. monocytogenes and their resistance to commonly used antibiotics indicate a potential public health risk. Given this situation, it is assumed that the system for monitoring antimicrobial resistance profile is extremely important to determine the appropriate treatment of human listeriosis. Therefore, the main goal of this study was to analyze the profile of antimicrobial resistance in strains isolated from humans in different regions of Brazil during the last four decades.

\section{METHODS}

\section{Bacterial strains}

Sixty-eight strains isolated from 1970 to 2008 were selected, including human clinical cases occurring in different regions of the country. The samples belong to the collection of Bacteriological 
Culture Collection Laboratory, Bacterial Zoonoses of the Oswaldo Cruz Institute/LABZOO/IOC/FIOCRUZ (Table 1), were maintained in tryptose agar semi-solid at $4^{\circ} \mathrm{C}$ throughout the study period and stored at $-20^{\circ} \mathrm{C}$ in $\mathrm{BHI}$ plus $20 \%$ glycerol.

TABLE 1 - Distribution of the strains of Listeria monocytogenes analyzed, according to source of origin and decade of isolation.

\begin{tabular}{lcccccc}
\hline & \multicolumn{5}{c}{ Decade } & \\
\cline { 2 - 6 } Source & 1970 & 1980 & 1990 & $2000-2008$ & Total \\
\hline CFS & 21 & 7 & 7 & 2 & 37 \\
\hline Blood & 4 & 7 & 7 & 8 & 26 \\
\hline Placental tissue & 1 & 0 & 0 & 0 & 1 \\
\hline Peritoneal fluid & 0 & 0 & 0 & 2 & 2 \\
\hline Vaginal discharge & 1 & 0 & 0 & 0 & 1 \\
\hline Cervical lymphadenitis & 0 & 0 & 1 & 0 & 1 \\
\hline Total & $\mathbf{2 7}$ & $\mathbf{1 4}$ & $\mathbf{1 5}$ & $\mathbf{1 2}$ & $\mathbf{6 8}$ \\
\hline
\end{tabular}

CFS: cerebrospinal fluid.

Phenotypic identification was performed in accordance with methods described by Rocourt \& Seeliger ${ }^{7}$. For the identification of serogroups/serovars, the technique of slide agglutination test was used, with poly and monovalent somatic and flagellar antisera prepared by LABZOO, according to the technical guidance of Seeliger \& Höhne ${ }^{8}$.

\section{Genotypic analysis by PCR}

The extraction of bacterial chromosomal DNA was performed using the Blood \& Tissue Dneasy Kit (Qiagen), in accordance with the manufacturer's specifications.

To determine the strains detected, primers targeting the $23 \mathrm{~S}$ rRNA genes (marker of genus), hly (marker of the species L. monocytogenes) and the markers D1 and D2 to were used confirm the identification of serogroups/serovars, according to literature ${ }^{9,10}$ (Table 2).

The amplification reactions were performed in volumes of $25 \mu \mathrm{l}$ with a primer concentration of $50 \mathrm{pmol} / \mu \mathrm{l}, 1 \mathrm{U}$ Taq polymerase, $0.2 \mathrm{mM}$ of each deoxynucleotide triphosphate, $2.5 \mathrm{mM} \mathrm{MgCl}_{2}$ and $50 \mathrm{ng}$ of DNA. For the PCR, the PX2 thermal cycler equipment (Thermo Fisher Scientific Inc. Waltham, MA, USA) was used under the following conditions (D1 $+\mathrm{D} 2$ primers): an initial step of $95^{\circ} \mathrm{C}$ for 3 min followed by 25 cycles at $95^{\circ} \mathrm{C} / 30 \mathrm{~s}, 56^{\circ} \mathrm{C} / 30 \mathrm{~s}, 72^{\circ} \mathrm{C} / 1 \mathrm{~min}$ and a final extension at $72^{\circ} \mathrm{C}$ for $10 \mathrm{~min}$. For amplification with primers $23 \mathrm{~S} \mathrm{rRNA}+$ hly $95^{\circ} \mathrm{C} / 5 \mathrm{~min}$ followed by 40 cycles of $95^{\circ} \mathrm{C} / 1 \mathrm{~min}$, $62^{\circ} \mathrm{C} / 1 \mathrm{~min}$ and $72^{\circ} \mathrm{C} / 1 \mathrm{~min}$, followed by a final extension at $72^{\circ} \mathrm{C}$ for $8 \mathrm{~min}$. All PCR products were determined by gel electrophoresis on $1 \%$ agarose $0.5 \mathrm{X}$ TBE buffer and visualized under UV light after staining with ethidium bromide. As molecular weight markers, the 2-log DNA ladders were used (New England BioLabs Inc.).

\section{Antimicrobial susceptibility}

Antimicrobial resistance was analyzed using the disk diffusion method, in accordance with the CLSI ${ }^{11}$, and was performed with standard discs (Oxoid) indicated for infections caused by

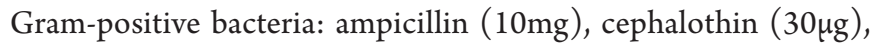
chloramphenicol $(30 \mu \mathrm{g})$, erythromycin $(15 \mu \mathrm{g})$, gentamicin (10mg), norfloxacin (10mg), rifampicin $(5 \mu \mathrm{g})$, sulfamethoxazole/ trimethoprim $(25 \mu \mathrm{g})$, teicoplanin $(30 \mu \mathrm{g})$, tetracycline $(30 \mu \mathrm{g})$ and vancomycin $(30 \mu \mathrm{g})$. To maintain quality control of performance and reliability of the results, the standard strains of Escherichia coli ATCC 25922 and Staphylococcus aureus ATCC 25923 were used.

The size of the inhibition zone was determined according to CLSI guidelines, 2009, for Staphylococcus spp ${ }^{11}$. Ampicillin and vancomycin were determined using the criteria established for Listeria spp. by Soussy et $\mathrm{al}^{12}$. According to their behavior before the use of antibiotics, the strains were classified as sensitive, intermediate and resistant.

\section{Determination of minimum inhibitory concentration}

After examination of the susceptibility by disk diffusion method in agar, 43 strains were randomly selected to determine the minimum inhibitory concentration (MIC) to ampicillin $(0.016-256 \mu \mathrm{g} / \mathrm{ml})$, tetracycline $(0.016-256 \mu \mathrm{g} / \mathrm{ml})$ and rifampicin $(0.016-256 \mu \mathrm{g} /$ $\mathrm{ml}$ ) by the E-test method, in accordance with the manufacturer's instructions ( $\mathrm{AB}$ Biodisk). The MIC values were defined as the lowest concentration of antibiotic able to inhibit growth and the rate of change of MIC50 (where 50\% of bacteria were inhibited) and MIC90 was calculated to specify the antimicrobial activity.

TABLE 2 - List of primers used in PCR.

\begin{tabular}{|c|c|c|c|c|}
\hline Primers & Forward primer & Reverse primer & Product & Specificity \\
\hline $\mathrm{D} 1^{\mathrm{a}}$ & CGATATTTATCTACTTTGTCA & TTGCTCCAAAGCAGGGCAT & $214 \mathrm{bp}$ & division I \\
\hline $\mathrm{D} 2^{\mathrm{b}}$ & GCGGAGAAAGCTATCGCA & ТТТТСАAАСАTAGGGCTA & $140 \mathrm{bp}$ & division II \\
\hline $23 \mathrm{~S}$ rRNA $^{\mathrm{c}}$ & GGGGAACССАСТАТСТТТАТТ & GGGCСТTCCAGACCGCTТCA & $239 \mathrm{bp}$ & Listeria genus \\
\hline Hly $^{\mathrm{d}}$ & GCCTGCAAGTCCTAAGACGCCAATC & СТTGCAACTGСТСТTTAGTAACAGC & $706 \mathrm{bp}$ & Listeria monocytogenes \\
\hline \multicolumn{5}{|c|}{ a - D1: Division I consists of serotypes $1 / 2 b, 3 b, 4 b, 4 d$, and $4 e$} \\
\hline \multicolumn{5}{|c|}{ b - D2: Division II consists of serotypes $1 / 2 \mathrm{a}, 1 / 2 \mathrm{c}, 3 \mathrm{a}$, and $3 \mathrm{c}$} \\
\hline \multicolumn{5}{|c|}{ c - 23S rRNA genes: marker of genus, } \\
\hline d - Hly: marl & er of the species Listeria monocytogenes & & & \\
\hline
\end{tabular}

\section{RESULTS}

Of the 68 strains analyzed, 37 (53\%) were isolated from cerebrospinal fluid (CSF), 26 (41\%) were isolated from blood and the remaining $6 \%$ were isolated from one of the following samples: placental tissue, vaginal secretion, cervical lymphadenitis and peritoneal fluid. The strains showed absolute consistency in the results obtained from phenotypic and genotypic analyzes. Antigenic characterization of L. monocytogenes permitted the identification of five serovars, with the highest frequency determined for serovar $4 \mathrm{~b}(\mathrm{n}=41,60.3 \%)$, followed by $1 / 2 \mathrm{a}(\mathrm{n}=14,20.6 \%)$ and $1 / 2 \mathrm{~b}$ $(\mathrm{n}=9,13.2 \%)$, and the more uncommon serovars, $1 / 2 \mathrm{c}(\mathrm{n}=2$, $2.9 \%), 3 b(n=1,1.4 \%)$ and $4 a b(n=1,1.4 \%)$. The temporal relations 
of the serotypes isolated are shown in Table 3. Currently, there is no criterion recommended by the CLSI for the interpretation of Listeria susceptibility, except for penicillin and ampicillin breakpoint, hence the breakpoints recommended for the interpretive criteria for Staphylococcus spp. were applied. All 68 strains analyzed were also susceptible to ampicillin, gentamicin, erythromycin, cephalothin, teicoplanin and vancomycin. Over the last four decades, a slight variation in the number of strains showing resistance to certain antimicrobials has been observed. In the 70s, only one strain of the serovar $1 / 2 \mathrm{a}(1.5 \%)$ was resistant to rifampicin isolated from CSF, and two serovar 4b (3\%) samples isolated during the $1990 \mathrm{~s}$ from blood were resistant to the association of trimethoprimsulfamethoxazole. In contrast, in the 1980s and from 2000 to 2008 , no resistance observed has been observed. A total of $29(42.6 \%)$ strains have shown intermediate resistance profile for antimicrobials: chloramphenicol (7.4\%), norfloxacin (27.9\%), tetracycline (5.9\%) and rifampicin (1.5\%), distributed over the last four decades.

All 43 strains tested against antimicrobial agents (rifampicin, ampicillin and tetracycline) using the E-test were sensitive. Rifampicin had the lowest MIC90

\section{TABLE 4 - An}

\begin{tabular}{lcccccc}
\hline & $\begin{array}{c}\text { Concentration } \\
(\mu / \mathrm{ml})\end{array}$ & $\begin{array}{c}\text { Susceptibility } \\
\text { breakpoints }\end{array}$ & $\begin{array}{c}\text { Resistance } \\
\text { breakpoints }\end{array}$ & $\begin{array}{c}\text { Range } \\
(\mu / \mathrm{ml})\end{array}$ & $\begin{array}{c}\text { MIC50 } \\
(\mu / \mathrm{ml})\end{array}$ & $\begin{array}{c}\text { MIC90 } \\
(\mu / \mathrm{ml})\end{array}$ \\
\hline Ampicillin & $0.016-256$ & $\leq 4$ & $>16$ & $0.25-4$ & 1.0 & 2.0 \\
\hline Tetracycline & $0.016-256$ & $\leq 4$ & $>8$ & $0.25-4$ & 1.0 & 2.0 \\
\hline Rifampicin & $0.016-256$ & $\leq 0.5$ & $>16$ & $0.016-0.94$ & 0.047 & 0.25 \\
\hline
\end{tabular}
$(0.25 \mu \mathrm{g} / \mathrm{ml})$, indicating its effective activity against Listeria. The values for ampicillin and tetracycline ranged from 0.25 to $4 \mu \mathrm{g} / \mathrm{ml}$ and showed a level of MIC90 of $2 \mu \mathrm{g} / \mathrm{ml}$ (Table 4).

\section{DISCUSSION}

Among the 13 serotypes of L. monocytogenes in the literature, serovar $4 \mathrm{~b}$ is primarily responsible for most of the outbreaks in humans $s^{5,13}$ while the serovar $1 / 2$ a prevails in food and in some regions of the world where it is more common in human cases ${ }^{14-16}$.

In relation to serovars of L. monocytogenes identified in this study, a higher incidence of serovar $4 \mathrm{~b}(60.3 \%)$ was observed, which is in agreement with research by Hofer et $\mathrm{al}^{17}$ and reports dating back to the 1970s. The frequency of serovar 4b was also demonstrated by Hofer et $\mathrm{al}^{18}$ in renal transplant recipients from the same hospital in São Paulo. In the same state, Lemes-Marques et al ${ }^{19}$ observed the incidence of the same serovar in clinical isolates from 1990 to 2005. Hofer et $\mathrm{al}^{20}$, performed phenotypic analysis of strains of L. monocytogenes isolated from clinical material from 1969 to 2000 in different regions of the country, noting the higher incidence of serotype $4 \mathrm{~b}$, followed by $1 / 2 \mathrm{a}$, in agreement with the results obtained in this study. In the aforementioned study ${ }^{20}$, the prevalence of serotype $4 \mathrm{~b}$ in CSF samples compared to blood isolates was also evident, which is consistent with the results obtained in this work, particularly for the 1970s. It is important to emphasize that all the strains tested were susceptible to ampicillin, which incidentally is the principal drug of choice for the treatment of listeriosis. It association with gentamicin has also been indicated and used successfully in the treatment of listeriosis, a situation supported by this study, since all strains were susceptible to gentamicin. The discrete level of rifampicin resistance in this study, another drug of choice for treatment is in agreement with the findings of Hofer \& Oliveira ${ }^{21}$, and Pore-Gluchowska \& Markiewicz ${ }^{6}$, who reported resistance in clinical strains from different parts of the world. It appears that virtually the same profile has been identified over the years and in different countries. In relation to tetracycline, this research highlighted the extreme sensitivity of the 68 strains to this drug, contrasting with the emergence of clinical strains resistant to tetracycline, related to the gene tet $M^{5,22,23}$.
TABLE 3 - Distribution of serotypes in 68 strains of Listeria monocytogenes isolated from 1970 to 2000 .

\begin{tabular}{lcccccc}
\hline & \multicolumn{9}{c}{ Decade } & & \\
\cline { 2 - 5 } Serotypes & 1970 & 1980 & 1990 & 2000 & Number Percentage \\
\hline $1 / 2 \mathrm{a}$ & 10 & 4 & 0 & 0 & 14 & 20.6 \\
\hline $1 / 2 \mathrm{~b}$ & 1 & 0 & 2 & 6 & 9 & 13.2 \\
\hline $1 / 2 \mathrm{c}$ & 1 & 0 & 0 & 1 & 2 & 2.9 \\
\hline $3 \mathrm{~b}$ & 0 & 0 & 0 & 1 & 1 & 1.5 \\
\hline $4 \mathrm{~b}$ & 14 & 10 & 13 & 4 & 41 & 60.3 \\
\hline $4 \mathrm{ab}$ & 1 & 0 & 0 & 0 & 1 & 1.5 \\
\hline Number $(\%)$ & $27(35.5)$ & $14(20.6)$ & $15(22.1)$ & $12(17.6)$ & 68 & 100.0 \\
\hline
\end{tabular}

No resistance to the association of trimethoprim-sulfamethoxazole was observed, which is important considering its nomination as an alternative in the treatment of listeriosis, primarily in patients with intolerance to penicillin ${ }^{5,24}$. The same result was obtained by LemesMarques et $\mathrm{al}^{19}$, although reports in the literature demonstrate resistance to trimethoprim ${ }^{25}$, as well as the combination of trimethoprim-sulfamethoxazole ${ }^{26,27}$. MICs with values up to $2 \mu \mathrm{g} /$ $\mathrm{ml}$ reinforce the need for microbiological surveillance.

In short, these results are compatible with most tests performed in various parts of the world, including Brazil, which showed a lower prevalence of strains resistant to antimicrobial therapy, indicated in cases of human listeriosis. However, the widespread use of antimicrobials in veterinary medicine, agriculture and particularly in animal food production could represent selective pressure on Listeria spp. In the environment in the future, allowing the acquisition of resistance mechanisms. Therefore, to evaluate the progression of resistance, it is essential to establish a program of continuous monitoring of antimicrobial susceptibility of isolates of L. monocytogenes and Listeria spp. isolated from human, animal, food and environmental sources.

\section{ACKNOWLEDGMENTS}

The authors would like to thank Evaldo Soares da Silva for his technical collaboration.

\section{CONFLICT OF INTEREST}

The authors declare that there is no conflict of interest.

FINANCIAL SUPPORT

IOC/FIOCRUZ, CNPq (Proc. 301545/2006-5).

\section{REFERENCES}

1. Mead PS, Slutsker L, Dietz V, Mccaig LF, Bresee JS, Shapiro C, et al. Food-related illness and death in the United States. Emerg Infect Dis 1999; 5:607-625. 
2. Hofer E, Hofer CB. Listeriose. In: Coura JR, editor. Dinâmica das Doenças Infecciosas e Parasitárias. Vol II. Rio de Janeiro: Guanabara Koogan; 2005. p. $1539-1545$.

3. Cruz CD, Martinez MB, Destro MT. Listeria monocytogenes: um agente infeccioso ainda pouco conhecido no Brasil. Alim Nutr 2008; 19:195-206.

4. Aureli P, Ferrine AM, Mannoni V, Hodzic S, Wedell-Weergaard C, Oliva B. Susceptibility of Listeria monocytogenes isolated from food in Italy to antibiotics. Int J Food Microbiol 2003; 83:325-330.

5. Charpentier E, Courvalin P. Minireview. Antibiotic Resistence in Listeria spp. Antimicrob Agents Chemother 1999; 43: 2103-2108.

6. Poros-Gluchowska J, Markiewicz Z. Antimicrobial resistance of Listeria monocytogenes. Acta Microbiol Pol 2003; 52:113-129.

7. Rocourt J, Schrettenbrunner A, Seeliger HPR. Differénciation biochimique des groupes génomiques des Listeria monocytogenes (sensu lato). Ann Microbiol (Inst Pasteur) 1983; 134A:65-71.

8. Seeliger HPR, Höhne K. Serotyping of L. monocytogenes and related species. In: Bergan T, Norris JR, editors. Methods in microbiology. Vol 13. London: Academic Press; 1979. p. 31-49.

9. Hudson JA, Lake RJ, Savill MG, Scholes P, Mccormick RE. Rapid detection of Listeria monocytogenes in ham samples using immunomagnetic separation followed by polymerase chain reaction. J Appl Microbiol 2001; 90:614-621.

10. Boruck MK, Douglas R, Call DR. Listeria monocytogenes serotype identification by PCR. J Clin Microbiol 2003; 41:5537-5540.

11. Clinical and Laboratory Standards Institute. Performance Standards for Antimicrobial Disk and Dilution Susceptibility Tests for Bacteria Isolated From Animals. Approved Standard. $3^{\text {rd }}$ ed. Wayne (PA): Clinical and Laboratory Standards Institute; 2009. M31-A3.28.

12. Soussy CJ, Ckuzel R, Courvalin P. Comité de I’Antibiogramme de la Société Française de Microbiologie. Definition and Determination of in vitro Antibiotic Susceptibility Breakpoints for Bacteria in France. Eur J Clin Microbiol Infect Dis 1994; 13:238-246.

13. Gasanov U, Hughes D, Hansbro PM. Methods for isolation and identification of Listeria spp. and Listeria monocytogenes: a review. FEMS Microbiol Rev $2005 ; 29: 851-875$

14. Jay JM. Prevalence of Listeria spp. in meat and poultry products. Food Control 1996; 7:209-214.

15. Schlech WF. Overview of listeriosis. Food Control 1996; 7:183-186.

16. Gilbreth SE, Call JE, Wallace FM, Scott VN, Chen Y, LuchanskyJB. Relatedness of Listeria monocytogenes isolates recovered from selected ready-to-eat foods and listeriosis patients in the United States. Appl Environ Microbiol 2005; $71: 8115-8122$

17. Hofer E, Pessoa GVA, Melles CEA. Listeriose humana. Prevalência dos sorotipos de Listeria monocytogenes isolados no Brasil. Rev Inst Adolfo Lutz 1984; 44:125-131.

18. Hofer CB, Melles CEA, Hofer E. Listeria monocytogenes in renal transplant recipients. Rev Inst Med Trop Sao Paulo 1999; 41:375-377.

19. Lemes-MarquesEG, Cruz CD, Destro MT.Pheno - and genotypic characterization of Listeria monocytogenes clinical isolates from the southwestern region of the State of São Paulo, Brazil. Braz J Microbiol 2007; 38:287-292.

20. Hofer E, Reis CMF, Hofer CB. Serovars of Listeria monocytogenes and related species isolated from human clinical specimens. Rev Soc Bras Med Trop 2006; 39:32-37.

21. Hofer E, Oliveira LMA. Sensibilidade antimicrobiana em amostras de Listeria isoladas de diferentes fontes e regiões do Brasil. Rev Microbiol 1988; 19:109112.

22. Morvan A, Moubareck C, Leclereq A, Hervé-Bazin M, Bremont S, Lecuit M, et al. Antimicrobial resistance of Listeria monocytogenes human strains isolated in France. Antimicrob Agentes Chemother 2010; 54:2728-2731.

23. Poyart-Salmeron C, Trien-Cuot P, Carlier C, Macgowan A, McLauchlin J, Courvalin P. Genetic basis of tetracycline resistance in clinical isolates of Listeria monocytogenes. Antimicrob Agents Chemother 1992; 36:463-466.

24. White DG, Zhao S, Simjee S, Wagner DD, Mcdemott PF. Antimicrobial resistance of foodborne pathogens. Microbes and Infection 2002; 4:405-412.
25. Charpentier E, Gerbaud G, Jacquet C, Rocourt J, Courvalin P. Incidence of antibiotic resistance in Listeria species. J Infect Dis 1995; 172:277-281.

26. Hofer E, Nascimento RS, Oliveira MA. Meningite por L. monocytogenes. Relato de casos em pacientes do Distrito Federal. Rev Soc Bras Med Trop 1998; 31:173177.

27. Catão RMR, Vigolvino WA, Andrade WT, Hofer E. Meningite por Listeria monocytogenes em Campina Grande - Paraíba, Brasil: relato de um caso. Rev Bras Anal Clin 2003; 35:81-83. 